\title{
$\ll$ Review» \\ Crossbred Chicken for Poultry Production in the Tropics
}

\author{
Mohammed A. Islam ${ }^{1,2}$ and Masahide Nishibori ${ }^{2}$ \\ ${ }^{1}$ Department of Animal Science, Bangabandhu Sheikh Mujibur Rahman \\ Agricultural University, Gazipur-1706, Bangladesh \\ ${ }^{2}$ Department of Bioresource Science, Graduate School of Biosphere Science, \\ Hiroshima University, Higashi-Hiroshima 739-8528, Japan
}

\begin{abstract}
The aim of the present review is to assess the potential usefulness of crossbred chickens in tropical environment. Poultry is a promising and emerging sector for poverty alleviation as well as an animal protein source in Bangladesh. Poultry production is yet lies in rural scavenging poultry in tropical country. Crossbreds are reared in scavenging, semi-intensive or intensive systems resulting in birds with good adaptability to tropical climate, highly resistant to disease and performing even better than pure exotic or indigenous chickens. Better growth performances are determined in indigenous naked neck (D. Nana) with Rhode Island Red (RIR), White Leghorn (WLH) or Fayoumi crossbreds in comparison with pure exotic, indigenous or other crossbreds. With respect to egg production, WLH $\times$ Fayoumi, RIR $\times$ Fayoumi, RIR $\times$ WLH and Fayoumi $\times$ WLH appear to be suitable combinations. However, crossbreds of D. Nana with RIR or Fayoumi produce more eggs than that of RIR or Fayoumi under scavenging conditions in a tropical climate. The best quality egg is found in WLH chickens but the highest egg shell thickness is found in D. Nana which affects hatchability of eggs. Of the above crosses, RIR $\times$ Fayoumi and their reciprocal crosses are found to be the best for fertility and hatchability. Accordingly D. Nana crossed with RIR or WLH or D. nana (indigenous full feathered chicken) results in improved fertility and hatchability of eggs. Although D. Nana crossed with an exotic broiler strain performs the best for meat yield traits, crossbred of D. Nana with RIR, WLH or Fayoumi improve meat yield traits. Therefore, the present review reveals that crossbreds of RIR $\times$ Fayoumi or D. Nana cockerels with RIR, WLH and Fayoumi hens may be considered for poultry production in tropical climate. This review emphasizes the use of D. Nana and its crosses with RIR, WLH or Fayoumi for their suitability in tropical regions.
\end{abstract}

Key words: chicken, crossbred, potentiality, production, tropics

J. Poult. Sci., 47: 271-279, 2010

\section{Introduction}

Bangladesh is one of the tropical countries in the world in which agriculture is the backbone of the nation, where population is increasing day by day and about $86 \%$ of people are directly or indirectly involved with agriculture. Among the various components of agriculture, poultry, which provides meat and egg as animal protein sources, is one of the most important components, preferred by all kinds of people. The requirement of meat and eggs for human beings is $120 \mathrm{~g} /$ day/head and 2 eggs/week/head, in a country where availability of meat and eggs is $12.6 \mathrm{~g} /$ day/head and 0.46 eggs/week/head, respectively (Huque, 1992). Therefore, this wide gap between demand and supply of animal protein as meat and eggs can be improved easily by poultry keeping (Das et al., 2008). This suggests that emphasis needs to be placed on increasing

Received: April 28, 2010, Accepted: July 2, 2010

Released Online Advance Publication: August 25, 2010

Correspondence: Dr. M.A. Islam, Department of Bioresource Science, Graduate School of Biosphere Science, Hiroshima University, HigashiHiroshima 739-8528, Japan. (E-mail: aminul_dgvc@yahoo.com) poultry production to provide required animal protein to human beings as well as to decrease unemployment. Therefore, scientists are trying to obtain maximum production, involving landless or marginal farmers with a minimum land, investment and time. A number of breeding techniques, methods and technology have been applied to achieve this goal. Some poultry industries have imported improved exotic varieties of chickens into Bangladesh which originated in temperate countries where they produce well. In tropical climate like Bangladesh, the production performance of these improved chickens is often below the standard of the breeder company because of their genetic make up inherent for temperate region, genotype $\times$ environment interaction, unsophisticated scientific management, inadequate nutrition and harsh environment, as well as high susceptibility to disease and lack of availability of good quality vaccines and therapeutics (Hutt, 1958; Al-Soudi and Al-Azzawi, 1974; Okoye and Aba-Adulugba, 1996; Tadelle et al., 2000; Singh et al., 2004). About $89 \%$ of poultry production continues to be under rural scavenging conditions in Bangladesh (Huque, 1996). Besbes (2009) showed that indigenous and local 
breeds share $90 \%$ of the total population in developing countries. Therefore, some NGO's, foreign aid projects and governmental organizations have concentrated on adopting a model for using crossbred chickens in scavenging or semi intensive systems to increase family poultry production (Das et al., 2008). Under extensive or traditional systems of poultry rearing, indigenous chickens performed better with respect to survivability, fertility and hatchability, although they have poor productivity (Huque and Haque, 1990; Barua et al., 1998b; Islam, 2000, 2006) which does not encourage farmers to extend the present level of their poultry operations. Indigenous chicken is low in productivity due to their inherent genetic characteristics, poor husbandry practices, seasonal effects, low level of nutrition, and broodiness (Sarkar and Bell, 2006; Besbes, 2009). Many studies have found that cross breeding of exotic with indigenous chickens resulted in birds that performed better, even superior to pure exotic chickens, with respect to body weight, egg production, survivability, fertility, hatchability and egg quality (Islam et al., 1981; Barua and Howlider, 1990; Khondoker et al., 1996; Rahman et al., 1998). Research carried out for the production of crossbreds, 'Sonali' from RIR and Fayoumi chickens reported increased egg production (Rahman et al., 1997; Fattah, 1999; Das et al., 2008). Rahman et al. (1997) reported 156 eggs/year in 'Sonali' crossbred hens. Lower productivity of indigenous chickens seems to be caused, at least in part, by management. A recent report stated that the productivity of indigenous chickens may be doubled in an improved management system (Chowdhury et al., 2006). In Bangladesh, numerous range of crossbreeding research studies has been done but there is no consensus among the findings. Crossbreeding is performed for the purpose of suitable genetic blending to fit under a given environment, break through in genetic limit and to have heterotic effect. Besbes (2009) reported improved body weight, egg production and survivability in crossbred chickens. Although to maintain crossbreeding program is too complex under village condition in most cases the cock has been used to utilize high-yielding breeds to up grade local chicken (Besbes, 2009). Considering the above facts, the present review will evaluate the potential of using crossbreds for poultry production and the development of a suitable genetic resource for future poultry production in hot-humid climate.

\section{Environment and Adaptability of Chickens}

Hot-humid climates are more detrimental than dry climate for chicken production (Horst and Petersen, 1981). Indigenous chickens are well adapted to harsh tropical environments and nutrition compared to the exotic chickens (Barua and Howlider, 1990; Horst, 1991; Ali et al., 1993). They can protect themselves and chicks from predatory animals (Khan, 1983) and can thrive under adverse environmental conditions such as poor housing and feeding, poor management and fluctuating temperature and humidity. They are also resistant to different diseases
(Barua and Howlider, 1991; Islam, 2000). Among the varieties of non-descript (not characterized) indigenous chickens, the naked neck type (tropically relevant major gene) is also available which has been found very promising, as it has a heat dissipation mechanism and is heat tolerant and therefore better adapted to warm climates (Merat, 1986; Horst, 1988; Deeb and Cahaner, 1996; Horst et al., 1996; Islam, 2000). On the other hand, exotic chickens suffer severely in the harsh tropical environment, showing reduced productivity and survivability and high susceptibility to disease and heat (Bohren et al., 1982; Barua et al., 1998a). Crossbred chickens have improved adaptability to tropical environments and are resistant to disease and heat compared to exotic pure breeds (Islam et al., 1981; Khondoker et al., 1996; Rahman et al., 1997; Barua et al., 1998a; Islam, 2006). Ali et al. (1993) reported improved productive adaptability of RIR $\times$ Fayoumi crossbreds compared to pure exotic chickens in Bangladesh. Crossbreds from indigenous naked neck (D. Nana) with exotic chickens are well adapted to harsh hot-humid climate compared to pure exotic chickens (Huque, 1999).

Crossbreeding research studies have been performed by different scientists but no final conclusion has been reached. The present study has reviewed update crossbreeding findings and concluded for future using of chicken genotypes in hot-humid climate.

\section{Performance of Exotic, Indigenous and Crossbred Chickens}

\section{Growth Performance}

Table 1 shows the growth performance of indigenous, exotic and crossbred chickens at different ages, where the broiler strain was found to be better for growth, feed conversion ratio (FCR) and mortality at 8 weeks of age compared to the exotic egg type, indigenous or crossbred chickens. However, broiler growth rate was severely depressed at high ambient temperature compared to Nana (improved naked neck) birds, as reported by Deeb and Cahaner (1996). Some authors reported that D. Nana chickens showed improved body weight and reduced mortality at hot-humid climate (Horst and Petersen, 1981; Merat, 1986; Barua and Yoshimura, 1997; Islam and Nishibori, 2009) and were superior to non-descript (not characterized) full feathered chickens in terms of growth, FCR and mortality. Singh et al. (1996) also observed better growth performance in Nana chickens compared to their full feathered counterparts in India. Naked neck chickens perform well in productive adaptability at hothumid climate, because of their association with the reduction in feather coverage, which can increase heat loss, and so indirectly increase feed intake and productive adaptability (Merat, 1986; Islam and Nishibori, 2009). Aseel $\times$ Australorp is found to show the tendencies to increase body weight compared to Australorp $\times$ Hampshire cross at 12 weeks of age (Table 1). The crossbreds from Bovan Brown $\times$ local chickens in Uganda were superior to local chickens in terms of daily gain though 
Table 1. Growth performance of indigenous, exotic and crossbreds chicken at different ages in Bangladesh

\begin{tabular}{|c|c|c|c|c|c|c|c|}
\hline Genetic resources & $\begin{array}{l}\text { Rearing } \\
\text { system }\end{array}$ & $\begin{array}{c}\text { Age } \\
\text { (week) }\end{array}$ & $\begin{array}{c}\text { BW } \\
\text { (g/bird) }\end{array}$ & $\underset{\text { (g/bird) }}{\text { FI }}$ & FCR & $\begin{array}{c}\text { Mortality } \\
(\%)\end{array}$ & Reference \\
\hline Indigenous full feathered (D. nana) & \multirow[t]{9}{*}{ Intensive (FM) } & \multirow[t]{9}{*}{8} & 316.5 & 1246.0 & 4.49 & 16.15 & \multirow[t]{10}{*}{ Islam et al. (2002b) } \\
\hline Indigenous naked neck (D. Nana) & & & 341.3 & 1495.2 & 4.85 & 16.10 & \\
\hline Redbro (R) & & & 1292.3 & 3599.9 & 2.90 & 16.10 & \\
\hline D. nana $\times$ D. Nana & & & 354.0 & 1498.0 & 4.97 & 9.50 & \\
\hline D. nana $\times$ Redbro & & & 614.4 & 2086.0 & 3.47 & 22.90 & \\
\hline D. Nana $\times$ D. nana & & & 388.9 & 1540.0 & 4.70 & 14.50 & \\
\hline D. Nana $\times$ Redbro & & & 645.0 & 2119.6 & 3.52 & - & \\
\hline Redbro $\times$ D. nana & & & 622.8 & 2282.0 & 3.80 & 17.30 & \\
\hline Redbro $\times$ D. Nana & & & 705.6 & 2206.0 & 3.21 & 4.40 & \\
\hline \multicolumn{3}{|c|}{ Significance level (Season $\times$ genetic group factorial exp. in CRD) } & $* * *$ & $* * *$ & $* * *$ & $*$ & \\
\hline Starbro broiler & Intensive (FM) & 8 & 1629.1 & 5570.9 & 3.39 & 6.00 & \multirow[t]{3}{*}{ Hossain et al.(1991) } \\
\hline Australorp Nana broiler & & & 1150.1 & 3227.3 & 2.80 & 2.04 & \\
\hline \multicolumn{3}{|c|}{ Significance level (genotype $\times$ weight factorial exp. in CRD) } & ** & $* *$ & $* *$ & $* *$ & \\
\hline Hilly & Intensive (FM) & 8 & 291.0 & 1293.6 & 4.44 & 16.25 & \multirow{2}{*}{$\begin{array}{l}\text { Islam and Nishibori } \\
(2009)\end{array}$} \\
\hline Yasine & & & 250.0 & 1660.4 & 6.64 & 11.35 & \\
\hline Aseel $\times$ Australorp & \multirow[t]{3}{*}{ Intensive (FM) } & \multirow[t]{3}{*}{12} & 1006.4 & 2816.5 & 2.80 & 19.04 & \multirow{3}{*}{$\begin{array}{l}\text { Howlider and Ahmed } \\
\text { (1982) }\end{array}$} \\
\hline Australorp $\times$ New Hampshire & & & 953.9 & 2637.5 & 2.76 & 14.28 & \\
\hline Significance level (CRD) & & & NS & $* *$ & NS & $*$ & \\
\hline D. nana & \multirow[t]{4}{*}{ Intensive (FM) } & \multirow[t]{4}{*}{$16-17$} & 833.2 & 4609.0 & 5.71 & 44.00 & \multirow{4}{*}{$\begin{array}{l}\text { Khondoker et al. } \\
\text { (1996) }\end{array}$} \\
\hline RIR & & & 973.2 & 5927.3 & 6.33 & 37.20 & \\
\hline D. nana $\times$ RIR & & & 964.7 & 4988.1 & 5.38 & 25.50 & \\
\hline Significance level (CRD) & & & $* *$ & NS & NS & $*$ & \\
\hline D. Nana & \multirow[t]{7}{*}{ Intensive (FM) } & \multirow[t]{7}{*}{$16^{-17}$} & 1213.8 & 5831.0 & 5.40 & 20.40 & \multirow[t]{7}{*}{ Haque et al. (1999) } \\
\hline WLH & & & 987.7 & 5093.2 & 5.40 & 13.60 & \\
\hline Fayoumi & & & 975.8 & 6080.9 & 6.20 & 3.30 & \\
\hline D. Nana $\times$ RIR & & & 1142.4 & 5854.0 & 5.10 & 32.50 & \\
\hline D. Nana $\times$ WLH & & & 1082.9 & 5640.6 & 5.20 & 19.00 & \\
\hline D. Nana $\times$ Fayoumi & & & 1094.8 & 5712.0 & 5.25 & 8.30 & \\
\hline Significance level (CRD) & & & $*$ & $* *$ & $* *$ & $*$ & \\
\hline Fayoumi & \multirow[t]{6}{*}{ Intensive (FM) } & \multirow[t]{6}{*}{$20-24$} & 1200.0 & 5844.0 & 7.46 & 0.00 & \multirow[t]{6}{*}{ Miah et al. (2002) } \\
\hline WLH & & & 1278.0 & 5806.0 & 6.87 & 7.70 & \\
\hline RIR & & & 1560.0 & 6386.0 & 5.46 & 0.00 & \\
\hline Fayoumi $\times$ WLH & & & 1309.0 & 6072.0 & 7.04 & 7.70 & \\
\hline Fayoumi $\times$ RIR & & & 1462.0 & 6060.0 & 6.15 & 8.77 & \\
\hline Significance level (CRD) & & & $* * *$ & NS & $* *$ & $* *$ & \\
\hline RIR $\times$ D. Nana & \multirow[t]{3}{*}{ Intensive (FM) } & \multirow[t]{3}{*}{$20-24$} & 1294.5 & 7864.7 & 6.19 & 10.00 & \multirow[t]{3}{*}{ Barua et al. (1998b) } \\
\hline WLH $\times$ D. Nana & & & 1291.2 & 8042.0 & 6.35 & 12.50 & \\
\hline Significance level (CRD) & & & NS & $*$ & NS & $*$ & \\
\hline RIR & \multirow[t]{4}{*}{ Intensive (FM) } & \multirow[t]{4}{*}{$20-24$} & 1469.5 & 6896.4 & 4.69 & 20.00 & Ali et al. (1993) \\
\hline Fayoumi & & & 1175.0 & 7089.1 & 6.03 & 25.00 & \\
\hline RIR $\times$ Fayoumi & & & 1445.3 & 6832.0 & 4.73 & 15.00 & \\
\hline Significance level (CRD) & & & $* *$ & NS & $* *$ & $* *$ & \\
\hline
\end{tabular}

$\mathrm{BW}=$ Body weight, $\mathrm{FI}=$ Feed intake, $\mathrm{FCR}=$ Feed conversion ratio, $\mathrm{WLH}=$ White Leghorn, $\mathrm{RIR}=$ Rhode Island Red, FM $=$ Floor Management, CRD $=$ Completely randomized design, ${ }^{*}, p<0.05 ; * *, p<0.01 ;{ }^{* * *}, p<0.001$; NS $=$ Non significant (Significance level is shown column wise for comparing among the genotypes of individual reference).

decreased the superiority gradually to zero at 6 months of age in case of $25 \%$ Bovan crosses (Sorensen and Ssewannyana, 2003). Bairagi et al. (1992) found better survivability in the crossbred of RIR or WLH male with indigenous Nana female compared to RIR or WLH chicken. Crossbred of RIR or WLH male with D. Nana female are heavier with lower FCR and mortality (Shivaprasad et al., 1994; Table 1). D. Nana, and D. Nana $\times$ RIR showed the better growth and feed conversion efficiency compared to pure exotic and other crosses at 16-17 weeks of age (Table 1). However, RIR $\times$ Fayoumi and Fayoumi $\times$ RIR are found to be the best performer among the crossbreds in terms of body weight and FCR at 20-24 weeks of age (Table 1). Azharul et al. (2005) reported that RIR $\times$ 
Fayoumi crossbred ('Sonali') performed better in terms of growth performances in intensive system under rural condition of Bangladesh compared to pure breed Fayoumi. Therefore, the crossbred of RIR $\times$ Fayoumi, Fayoumi $\times$ RIR, RIR or WLH male with D. Nana female may be useful for their improved growth and feed conversion efficiency, and lower mortality at hot-humid climate.

\section{Egg Production Performance}

WLH $\times$ Fayoumi is found to be the highest egg producing combination among the available genetic resources in Bangladesh when reared in intensive management systems, but not in scavenging or semi-scavenging systems (Table 2). Although indigenous chickens have lower egg production (45 eggs/year) and egg weight ( $35 \mathrm{~g} / \mathrm{egg}$ ) (Islam, 2006) under the scavenging system, they attained sexual maturity earlier (D. nana-148 days and D. Nana145 days) with a lower mortality under the intensive system (Table 2). However, D. Nana performed better in terms of sexual maturity, egg production, egg weight and mortality, compared to D. nana chickens (Islam, 2000; Islam and Nishibori, 2009, Table 2). Islam et al. (1981) reported 45 eggs/hen/year, $35 \mathrm{~g} / \mathrm{egg}$ and delayed sexual maturity (177 days) in D. nana chickens. The crosses of RIR $\times$ Fayoumi, Fayoumi $\times$ RIR, Fayoumi $\times$ WLH and RIR $\times$ WLH resulted in earlier sexual maturity, and higher egg production (Ambar et al., 1999; Rahman et al., 2004). Rahman et al. (2004) found that sexual maturity of Fayoumi $\times$ RIR, and RIR $\times$ Fayoumi occurred at 151 and 147 days, and their hen-day egg production were $52.3 \%$ and $48.2 \%$, respectively (Table 2). Miah et al. (2002) reported sexual maturity, and hen-day egg production of Fayoumi $\times$ RIR at 150 days, and $51.0 \%$, respectively (Table 2). Ambar et al. (1999) suggested using the crossbred of RIR $\times$ Fayoumi called 'Sonali' for its superior egg production and livability under semi-intensive systems. Haque and Howlider (2000) showed better egg production in D. Nana $\times$ Fayoumi and D. Nana $\times$ RIR under scavenging condition compared to exotic chickens.

Table 2. Egg production performance of indigenous, exotic and crossbreds chicken in Bangladesh

\begin{tabular}{|c|c|c|c|c|c|c|c|}
\hline Genetic resources & Rearing system & $\begin{array}{l}\text { Laying } \\
\text { period }\end{array}$ & $\begin{array}{l}\text { Sexual maturity } \\
\text { (day) }\end{array}$ & $\begin{array}{c}\text { Hen day egg } \\
\text { production }(\%)\end{array}$ & $\begin{array}{l}\text { Egg weight } \\
\text { (g) }\end{array}$ & $\begin{array}{c}\text { Mortality } \\
(\%)\end{array}$ & Reference \\
\hline D. nana & Intensive (FM) & 1 year & 195 & 12.05 & 38.20 & & Huque et al. (2001) \\
\hline D. Nana & & & 195 & 26.84 & 42.55 & & \\
\hline Hilly & & & & 25.10 & 42.00 & & \\
\hline Yasine & & & & 16.00 & 44.00 & & \\
\hline Aseel & & & & 9.40 & 45.00 & & \\
\hline WLH $\times$ Fayoumi & & & & 61.63 & 49.45 & 10.50 & \\
\hline WLH $\times$ Australorp & & & & 53.12 & 56.15 & 11.12 & \\
\hline $\mathrm{WLH} \times \mathrm{RIR}$ & & & & 58.71 & 55.10 & 15.00 & \\
\hline $\mathrm{RIR} \times \mathrm{BPR}$ & & & & 56.79 & 57.27 & 16.50 & \\
\hline $\mathrm{RIR} \times \mathrm{WLH}$ & & & & 55.85 & 57.89 & 17.50 & \\
\hline Fayoumi $\times$ D. Nana & & & 168 & 41.00 & 46.00 & & \\
\hline Fayoumi $\times$ Hilly & & & 162 & 35.00 & 45.00 & & \\
\hline BPR $\times$ Fayoumi & & & & 58.13 & 49.66 & 14.60 & \\
\hline D. autosomal dwarf & Intensive (FM) & 1 year & & 33.50 & 39.12 & & Yeasmin and Howlider \\
\hline D. nana & & & & 24.69 & 39.99 & & (1998) \\
\hline Significance level ( $t$-test) & & & & $* *$ & $* *$ & & \\
\hline Fayoumi & Intensive (FM) & 1 year & 126 & 52.66 & 35.51 & 12.00 & Miah et al. (2002) \\
\hline WLH & & & 164 & 42.00 & 48.58 & 12.53 & \\
\hline RIR & & & 164 & 43.33 & 53.12 & 25.00 & \\
\hline Fayoumi $\times$ WLH & & & 148 & 50.66 & 45.90 & 15.00 & \\
\hline Fayoumi $\times$ RIR & & & 150 & 51.00 & 44.34 & 12.50 & \\
\hline Significance level (CRD) & & & $* *$ & $*$ & $* *$ & NS & \\
\hline RIR $\times$ Fayoumi & Intensive & 1 year & 147 & 48.20 & 49.40 & 16.20 & Rahman et al. (2004) \\
\hline Fayoumi $\times$ RIR & (cage) & & 151 & 52.30 & 48.70 & 13.40 & \\
\hline \multicolumn{3}{|l|}{ Significance level ( $t$-test) } & NS & $* *$ & NS & NS & \\
\hline D. nana & Intensive (FM) & $\begin{array}{l}5 \\
\text { months }\end{array}$ & 148 & 12.60 & 37.90 & 24.45 & Islam et al. (2000) \\
\hline D. Nana & & & 145 & 16.73 & 40.50 & 18.86 & \\
\hline Redbro & & & 172 & 31.53 & 60.50 & 8.50 & \\
\hline Significance level (strain $>$ & $\times$ sex factorial ex & p. in CRD & NS & $* *$ & $* * *$ & NS & \\
\hline
\end{tabular}

D. nana $=$ Indigenous full feathered, $\mathrm{D}$. Nana $=$ Indigenous naked neck, WLH $=$ White Leghorn, $\mathrm{RIR}=\mathrm{Rhode}$ Island $\mathrm{Red}, \mathrm{BPR}=\mathrm{Barred}$ Plymouth Rock, FM=Floor Management, $\mathrm{CRD}=$ Completely randomized design, ${ }^{*}, p<0.05 ; * *, p<0.01 ; * * *, p<0.001$; NS $=$ Non significant (Significance level is shown column wise for comparing among the genotypes of individual reference). 
Naked neck with exotic crossbred chicken performs better in productivity, because of higher genetic distance between indigenous and exotic breed and in environmental stress situation a higher degree of heterosis should be expected (Horst, 1991). However, exotic breeds, WLH $\times$ WLH, RIR $\times$ RIR chickens perform better under intensive systems than D. Nana or the crossbreds from D. Nana with RIR or WLH.

Exotic breeds like RIR, WLH and Fayoumi, which are typically used for crossbreeding, were imported into Bangladesh many decades ago. So the purity of such imported breeds is doubtful and continuous inbreeding may now have caused them to be less productive (Latif, 2001). In developing countries, crossbreds from indigenous with exotic chickens perform better under scavenging or semiscavenging condition (Das et al., 2008). Crossbred from indigenous and exotic chicken perform better for improving productivity because of their combining ability, genetic make up and reproductive fitness (Besbes, 2009). But in Ethiopia, an experimental crossbreeding program which involved exchanging cockerels or pullets or fertile eggs of exotic birds to village farmers resulted in adverse alterations in the genetic make up of indigenous chickens (Tadelle et al., 2000). However, this conclusion certainly should not over rule the gene $\times$ environment interaction. Several major genes such as $\mathrm{Na}$ (naked neck), f (frizzle), adw (autosomal dwarf), dw (sex-linked dwarf), are still segregating in indigenous population (Yeasmin and Howlider, 1998). D. autosomal dwarf is found to be better for egg production than that of D. nana. However, of the indigenous chickens, D. Nana is the best performer in terms of egg production, egg weight and mortality (Table 2).
Horst (1991) found improved egg production in crossbreeds of Nana $\times$ Dahlem Red (German strain) and WLH $\times$ Kadaknath (Indian) chickens. Egyptian local chickens (Dandarawi and Fayoumi) were lower for egg production (202.2 and 212.5 eggs/year, respectively) in temperate conditions compared to Dahlem Red (279 eggs/year) but, in warm climates, egg production was depressed in both, although the depression was lower in Egyptian chickens (137.9 and 161.0 eggs, respectively) than in Dahlem Red chickens (181.7 eggs) (Valle-Zarate et al., 1988). Investigations proved that pure exotic breed Lohmann Brown produced 303 eggs/year under the optimal conditions but only 140 eggs under semi-scavenging conditions, while the crossbred-'Sonali' produced 156 eggs under semi-scavenging condition (Sorensen, 1997). In India a crossbred hen from Aseel $\times$ CARI Red, called 'CARI Nirbheek' has been developed for improving egg production under traditional condition. This crossbred was able to produce 163 eggs annually with a survival rate of 90-95\% (Singh et al., 2004). Therefore, RIR $\times$ Fayoumi, Fayoumi $\times$ RIR, WLH $\times$ Fayoumi and D. Nana $\times$ RIR or WLH or Fayoumi under scavenging or semi-intensive system in tropical climate may be worthy combinations for improving egg production.

\section{Egg Quality Traits}

Research on egg quality in Bangladesh is scarce. Egg quality is influenced by genetic and non-genetic factors such as season, environment and feed (Salahuddin and Howlider, 1991). Overall the best quality egg was for WLH chickens (Table 3). D. adwarf is found to be the tendencies to increase Haugh unit, albumen and yolk dry matter compared to D. nana (Table 3). But statistically

Table 3. Egg quality traits of indigenous and exotic chicken in Bangladesh

\begin{tabular}{|c|c|c|c|c|c|c|c|c|c|c|c|c|}
\hline $\begin{array}{l}\text { Genetic } \\
\text { resources }\end{array}$ & $\begin{array}{l}\text { Egg } \\
\text { weight } \\
\text { (g) }\end{array}$ & $\begin{array}{l}\text { Shape } \\
\text { index }\end{array}$ & $\begin{array}{c}\text { Yolk } \\
\text { index } \\
\text { (Y1) }\end{array}$ & $\begin{array}{l}\text { Albumen } \\
\text { index } \\
\text { (A1) }\end{array}$ & $\begin{array}{l}\text { Haugh } \\
\text { unit } \\
(\mathrm{HU})\end{array}$ & $\begin{array}{l}\text { Yolk } \\
(\%)\end{array}$ & $\mathrm{Al} \%$ & $\begin{array}{l}\text { Shell } \\
\text { thickness } \\
(\mathrm{mm})\end{array}$ & $\begin{array}{l}\text { Al: } \\
\text { Yolk } \\
\text { ratio }\end{array}$ & $\begin{array}{c}\text { Al dry } \\
\text { matter } \\
(\%)\end{array}$ & $\begin{array}{l}\text { Y1 dry } \\
\text { matter } \\
(\%)\end{array}$ & Reference \\
\hline RIR & 52.50 & 71.63 & 0.446 & 0.068 & 82.55 & 32.25 & 58.36 & 34.35 & 1.80 & & & Salahuddin \\
\hline WLH & 54.59 & 70.28 & 0.460 & 0.076 & 83.49 & 30.16 & 60.51 & 34.55 & 2.00 & & & and \\
\hline Fayoumi & 38.37 & 61.04 & 0.430 & 0.067 & 77.87 & 31.59 & 59.85 & 32.82 & 1.89 & & & Howlider \\
\hline Starcross & 54.73 & 69.50 & 0.471 & 0.076 & 83.12 & 31.93 & 58.51 & 33.55 & 1.81 & & & (1991) \\
\hline D. Nana & 53.53 & 70.81 & 0.443 & 0.069 & 82.50 & 32.00 & 58.77 & 33.46 & 1.82 & & & \\
\hline Sig. level & $* *$ & $* *$ & $* *$ & $* *$ & $* *$ & $* *$ & $* *$ & $* *$ & $* *$ & & & \\
\hline D. nana & 38.05 & & & & & & & 33.50 & & 13.75 & 51.15 & Islam et al. \\
\hline D. Nana & 40.35 & & & & & & & 35.00 & & 13.60 & 48.50 & $(2001 a)$ \\
\hline Redbro & 64.25 & & & & & & & 32.00 & & 12.10 & 55.30 & \\
\hline Sig. level & $* * *$ & & & & & & & NS & & NS & NS & \\
\hline D. nana & 39.99 & 76.64 & 0.390 & 0.080 & 82.23 & & & & & 14.24 & 52.27 & Yeasmin and \\
\hline D. adwarf & 39.12 & 76.87 & 0.390 & 0.080 & 81.26 & & & & & 13.43 & 51.03 & $\begin{array}{l}\text { Howlider } \\
\text { (1998) }\end{array}$ \\
\hline Sig. level & $* *$ & NS & NS & NS & NS & & & & & NS & NS & \\
\hline
\end{tabular}

$\mathrm{RIR}=$ Rhode Island Red, WLH $=$ White Leghorn, D. nana $=$ Indigenous full feathered, D. Nana $=$ Indigenous naked neck, $\mathrm{D}$. adwarf $=$ Indigenous autosomal dwarf chicken, ${ }^{* *}, p<0.01 ; * * *, p<0.001$; NS $=$ Non significant (Significance level is shown column wise for comparing among the genotypes of individual reference), Rearing system: Intensive (floor management), Data were analysed using breed $\times$ season, and season $\times$ genotype factorial exp. in Completely randomozed design, and $t$-test by the Authors of Salahuddin and Howlider (1991), Islam et al. (2001a) and Yeasmin and Howlider (1998), respectively. 
no differences were found among the eggs of indigenous chickens for the traits of Haugh unit, albumen and yolk dry matter (Table 3). However, the highest egg shell thickness is found in D. Nana chickens which affect the hatchability of the eggs (Al-Soudi and Al-Jebouri, 1979) (Table 3). Al-Soudi and Al-Jebouri (1979) reported the highest percentage of egg shell thickness in the Iraqi indigenous chicken. However, D. Nana is superior to D. nana with respect to egg quality. Therefore, WLH or D. Nana is found to be suitable genotype for producing better quality egg.

\section{Fertility and Hatchability}

Table 4 shows the fertility and hatchability of different genetic resources of chickens. Exotic chickens show better fertility than indigenous chickens in intensive systems. In a hot-humid environment, scavenging indigenous chickens had better fertility than exotic chickens because of heat stress (A1-Soudi and A1-Jebouri, 1979). These authors reported better fertility $(91.3 \%)$ and hatchability (38.6\%) in Iraqi chicken than in New Hampshire $(83.4 \%$ fertility and 33.4\% hatchability). Kamble et al. (1996) reported the fertility of $85 \%$ and $66 \%$ in Indian fullfeathered Kadakanath and Nana chickens, respectively. However, D. nana is better than D. Nana for fertility and hatchability and comparable to exotic chickens (Table 4). Among the crosses, RIR $\times$ Fayoumi and Fayoumi $\times$ RIR crosses are the best combinations for fertility and hatchability of eggs. Fertility and hatchability of RIR $\times$ Fayoumi crosses are $96.9 \%$ and $81.1 \%$, respectively (Table 4). D. Nana crossed with exotic Redbro or D. nana chickens had improved hatchability compared to exotic Redbro chickens (Table 4). Islam et al. (1981) observed the increased fertility from crosses of exotic males with D. nana female chickens. The hatchability of $\mathrm{WLH} \times \mathrm{D}$. nana crosses is $80.61 \%$ (Table 4). Hatchability is also affected by egg shell quality, with the hatchability of thin shelled eggs being 3-9\% lower than the thicker shelled eggs (Bennet, 1992). Thin egg shells result in reduced hatchability and weakening of the embryo (Peebles and Brake, 1987). Therefore, RIR $\times$ Fayoumi, Fayoumi $\times$ RIR and D. Nana

Table 4. Fertility and hatchability of indigenous, exotic chicken and their crosses

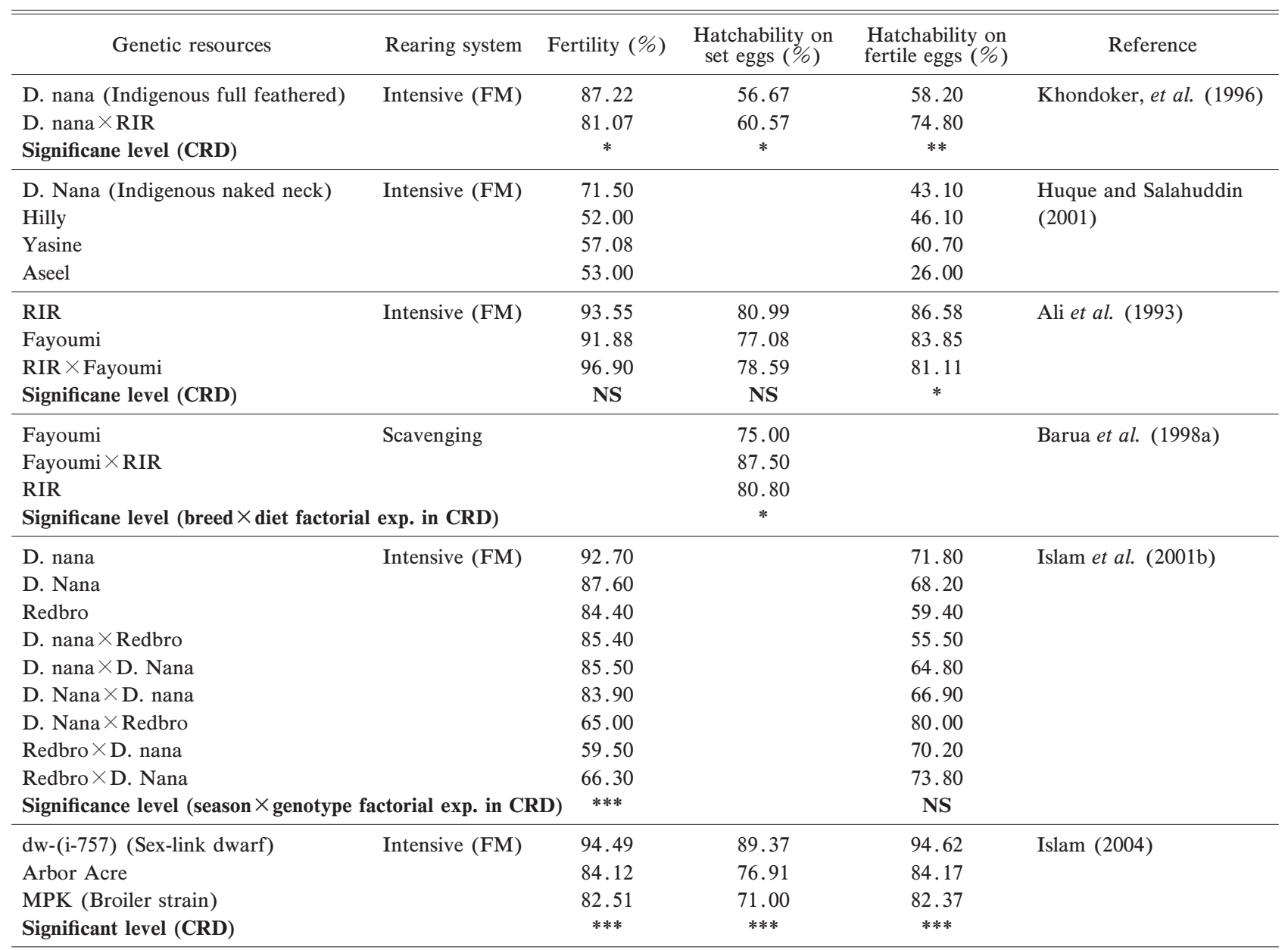

$\mathrm{RIR}=$ Rhode Island Red, WLH $=$ White Leghorn, $\mathrm{FM}=$ Floor Management, $\mathrm{CRD}=$ Completely randomized design, $*, p<0.05 ; * *, p<$ $0.01 ; * * *, p<0.001 ; \mathrm{NS}=$ Non significant (Significance level is shown column wise for comparing among the genotypes of individual reference). 
Table 5. Meat yield of different genetic resources of chicken at different ages

\begin{tabular}{|c|c|c|c|c|c|c|}
\hline Genetic resources & Rearing system & $\begin{array}{c}\text { Age group } \\
\text { (days) }\end{array}$ & $\begin{array}{l}\text { Live weight } \\
\text { (g/bird) }\end{array}$ & $\begin{array}{c}\text { Dressing } \\
(\%)\end{array}$ & $\begin{array}{l}\text { Total meat } \\
(\%)\end{array}$ & Reference \\
\hline D. nana $\times$ D. nana & \multirow[t]{10}{*}{ Intensive (FM) } & \multirow[t]{10}{*}{56} & 358.3 & & 30.0 & \multirow[t]{10}{*}{ Islam et al. (2002a) } \\
\hline D. nana $\times$ D. Nana & & & 374.2 & & 31.5 & \\
\hline D. nana $\times$ Redbro & & & 732.7 & & 32.0 & \\
\hline D. Nana $\times$ D. nana & & & 391.3 & & 31.0 & \\
\hline D. Nana $\times$ D. Nana & & & 364.5 & & 31.5 & \\
\hline D. Nana $\times$ Redbro & & & 795.0 & & 31.5 & \\
\hline Redbro $\times$ D. nana & & & 670.7 & & 31.5 & \\
\hline Redbro $\times$ D. Nana & & & 832.1 & & 33.5 & \\
\hline Redbro $\times$ Redbro & & & 1224.2 & & 32.0 & \\
\hline Significant level $(S \times G$ factorial exp. in $\mathbf{C R D})$ & & & $* * *$ & & $* * *$ & \\
\hline D. Nana & \multirow[t]{8}{*}{ Intensive (FM) } & \multirow[t]{8}{*}{84} & 1120.0 & 59.4 & 26.2 & \multirow{8}{*}{$\begin{array}{l}\text { Haque and Howlider } \\
\text { (2000) }\end{array}$} \\
\hline RIR & & & 1147.0 & 57.6 & 22.3 & \\
\hline WLH & & & 910.0 & 59.0 & 23.0 & \\
\hline Fayoumi & & & 970.0 & 62.2 & 24.5 & \\
\hline D. Nana $\times$ RIR & & & 1275.0 & 58.7 & 24.3 & \\
\hline D. Nana $\times$ WLH & & & 1130.0 & 64.7 & 26.8 & \\
\hline D. Nana $\times$ Fayoumi & & & 1103.0 & 63.1 & 27.1 & \\
\hline Significant level (CRD) & & & $* *$ & $*$ & $* *$ & \\
\hline D. nana & Intensive (FM) & \multirow[t]{3}{*}{120} & & 60.9 & 25.1 & \multirow[t]{3}{*}{ Howlider et al. (1995) } \\
\hline D. Nana & & & & 62.9 & 30.1 & \\
\hline Significant level (Regressio & & & & $* *$ & $* *$ & \\
\hline D. nana & \multirow[t]{3}{*}{ Scavenging } & \multirow[t]{3}{*}{150} & 970.0 & 53.6 & 29.9 & \multirow{3}{*}{$\begin{array}{l}\text { Barua and Howlider } \\
\text { (1991) }\end{array}$} \\
\hline D. Nana & & & 1010.0 & 57.1 & 37.3 & \\
\hline Significant level (Regressio & & & $* *$ & $* *$ & $* *$ & \\
\hline D. Nana & \multirow[t]{8}{*}{ Intensive (FM) } & \multirow[t]{8}{*}{120} & 697.0 & 54.3 & 26.9 & \multirow[t]{8}{*}{ Haque et al. (1999) } \\
\hline RIR & & & 732.0 & 54.4 & 25.8 & \\
\hline WHL & & & 659.0 & 51.2 & 24.2 & \\
\hline Fayoumi & & & 806.0 & 54.0 & 25.3 & \\
\hline D. Nana $\times$ RIR & & & 666.0 & 55.8 & 26.8 & \\
\hline D. Nana $\times$ WLH & & & 622.0 & 56.2 & 26.6 & \\
\hline D. Nana $\times$ Fayoumi & & & 710.0 & 54.3 & 25.3 & \\
\hline Significant level (CRD) & & & $*$ & $*$ & $* *$ & \\
\hline
\end{tabular}

D. Nana $=$ Indigenous naked neck, D. nana $=$ Indigenous full feathered, RIR $=$ Rhode Island Red, WLH $=$ White Leghorn, FM $=$ Floor Management, $\mathrm{CRD}=$ Completely randomized design, ${ }^{*}, p<0.05 ; * *, p<0.01 ; * * *, p<0.001$ (Significance level is shown column wise for comparing among the genotypes of individual reference), $\mathrm{S}=$ Season, $\mathrm{G}=$ Genetic group.

with RIR or Fayoumi may be the most suitable combination to have improved fertility and hatchability.

\section{Meat Yield Traits}

Research work on meat yield traits is scanty (Table 5). The highest total meat yield $(37.3 \%)$ is found in D. Nana followed by Redbro $\times$ D. Nana $(33.5 \%)$ and Redbro $\times$ Redbro (32.0\%) crossbred (Islam et al., 2002a). Crossbreds from D. Nana with WLH or Fayoumi resulted in improved dressed and total meat yield in comparison with exotic or D. nana chicken (Table 5). Azharul et al. (2005) found the higher breast, dark and total meat yield in crossbred of RIR $\times$ Fayoumi (Sonali) compared with Fayoumi breed. D. Nana yielded higher dressing and total meat $(\%)$ than that of D. nana counterparts (Islam and Nishibori, 2009). Paul et al. (1990) found that D. nana hens were higher than broiler chickens at $6.90 \%$ dressed carcass, $11.42 \%$ total meat, $3.56 \%$ breast and $7.65 \%$ dark meat. Crossbreds of D. Nana cocks with RIR, WLH or
Fayoumi hens improve the percentage of dressing and total meat compared with exotic pure breeds at 84 days of age (Table 5). So, D. Nana with RIR, WLH or Fayoumi may be the worthy combinations for yielding improved meat.

\section{Conclusions}

From the present review, it is concluded that crossbreds may be useful for poultry production under semi-intensive or scavenging rearing systems in tropical climates because of their adaptability and resistance to disease. Some crosses such as RIR $\times$ Fayoumi, RIR $\times$ WLH, Fayoumi $\times$ RIR, D. Nana $\times$ RIR or WLH, and Redbro $\times$ D. Nana were found to be the most suitable combination for their better growth, egg production, fertility, hatchability and meat yield traits compared to the pure exotic chickens. D. Nana is superior to D. nana chicken in terms of better productive adaptability in a tropical climate. However, 
crossbreds of D. Nana with RIR, WLH or Fayoumi are found to have improved production and reproduction under scavenging or semi-intensive systems in a tropical climate. Therefore the present review suggests using the crossbreds of RIR with Fayoumi or indigenous naked neck with RIR, WLH or Fayoumi for prevailing better production in tropical climate.

\section{References}

Al-Soudi KA and Al-Azzawi I. Protein requirements of two breeds of laying hens in subtropical climate. Indian Journal of Animal Science, 44: 703. 1974.

Al-Soudi KA and Al-Jebouri MAJ. Production potential in subtropics climate of native Iraqi chicken compared to White Leghorn, New Hampshire and their cross. World's Poultry Science Journal, 35: 227-235. 1979.

Ali MI, Wahid MA, Howlider MAR and Yeasmin T. Reproduction and growth of Rhode Island Red (RIR), Fayoumi (FO) and RIR $\times$ FO chicken in Bangladesh. Poultry Adviser, 24: 47-50. 1993.

Ambar MAJ, Bhuiyan AKFH, Hoque MA and Amin MR. Ranking of some pure and crossbred chicken using scoring indices. Indian Journal of Poultry Science, 34: 140-146. 1999.

Azharul IM, Ranvig H and Howlider MAR. Comparison of growth rate and meat yield characteristics of cockerels between Fayoumi and Sonali under village conditions in Bangladesh. Livestock Research for rural Development, 17: http://www. Irrd.org/Irrd17/2/azha17021.htm. 2005.

Bairagi MK, Hamid MA, Islam MA and Howlider MAR. The effect of incorporation of naked neck gene from Bangladeshi indigenous chicken to Rhode Island Red and White Leghorn on growth. Poultry Adviser, 25: 43-46. 1992.

Barua A and Howlider MAR. Prospects of of native chicken in Bangladesh. Poultry Adviser, 22: 57-61. 1990.

Barua A and Howlider MAR. Meat yield of free range naked neck and full feathered Bangladeshi chicken. Indian Journal of Animal Sciences, 61: 772-775. 1991.

Barua A, Howlider MAR and Yoshimura Y. A study on the performance of Fayoumi, Rhode Island Red and Fayoumi $\times$ Rhode Island chickens under Rural condition of Bangladesh. Asian-Australasian Journal of Animal Sciences, 11: 635-641. 1998a.

Barua A, Howlider MAR and Yoshimura Y. Indigenous naked neck fowl of Bangladesh. World's Poultry Science Journal, 54: 279-286. 1998b.

Barua A and Yoshimura Y. Rural poultry keeping in Bangladesh. World's Poultry Science Journal, 53: 388-394. 1997.

Bennet CD. The influence of shell thickness on hatchability in commercial broiler breeder flocks. Journal of Applied Poultry Research, 1: 61-65. 1992.

Besbes B. Genotype evaluation and breeding of poultry for performance under sub-optimal village conditions. World's Poultry Science Journal, 65: 260-271. 2009.

Bohren BB, Rogler JC and Carson JR. Survival under heat stress of lines selected for fast and slow growth at two temperatures. Poultry Science, 61: 1804-1808. 1982.

Chowdhury SD, Ahmed S and Hamid MA. Improve feeding of Desi chicken reared in confinement. The Bangladesh Veterinarian, 23: 29-35. 2006.

Das SC, Chowdhury SD, Khatun MA, Nishibori M, Isobe $\mathrm{N}$ and
Yoshimura Y. Poultry production profile and expected future projection in Bangladesh. World's Poultry Science Journal, 64: 99-118. 2008.

Deeb $\mathrm{N}$ and Cahaner A. The effect of the Naked neck $(\mathrm{Na})$ gene on broilers stocks differing in growth rate. In: Proceedings of the XX World's Poultry Congress, IV, pp. 11. 1996.

Fattah KA. Poultry as a tool in poverty eradication and promotion of gender equality. In: Proceedings of Workshop on Poverty Eradication and Promotion of Gender Equality. Tune Landboskole. Denmark, pp: 16-28. 1999.

Haque ME and Howlider MAR. Growth and meat yield in native naked neck, exotic chicken and their crossbreds; $F_{2}$ generation. Indian Journal of Animal Science, 70: 501-503. 2000.

Haque ME, Howlider MAR and Huque QME. Growth performance and meat yield characteristics of native naked neck and their crosses with exotic chicken. Journal of Applied Animal Research, 16: 81-86. 1999.

Horst P. Using major gene for feather restriction. Poultry Misset, 4: 8-9. 1988.

Horst P. Native fowl as a reservoir for genomes and major genes with direct and indirect effects on the adaptability and their potential for tropically oriented breeding plans-a review. Animal Research and Development, 33: 63-79. 1991.

Horst P, Mathur PK and Valle Zarate A. Breeding policies for specific tropical environments using appropriate combination of major genes with improved fowls. In: Proceedings of the XX World's Poultry Congress, 1, pp. 633-640. 1996.

Horst $\mathrm{P}$ and Petersen J. The effect of dwarf gene on the adaptability of laying hens to high environmental temperatures. Animal Research and Development, 13: 69-74. 1981.

Hossain MM, Howlider MAR and Hossain MJ. Growth performance and meat yield of naked neck Australorps and broiler chickens in a hot-humid environment. The Bangladesh Veterinarian, 8: 4-7. 1991.

Howlider MAR and Ahmed S. Studies of the production characteristics of some crossbred chicken under local condition of Bangladesh. Bangladesh Veterinary Journal, 16: 47-51. 1982.

Howlider MAR, Begum F, Islam MS and Wahid MA. Feathering and meat yield of full feathered and naked neck indigenous chicken of Bangladesh. Journal of Applied Animal Research, 8: 191-195. 1995.

Huque QME. A research report on current status of poultry production and marketing system in Bangladesh. Bangladesh Livestock Research Institute, Savar, Bangladesh. 1992.

Huque QME. Improving skill of the small farmers in poultry management. In: Proceedings of the XX World's Poultry Congress, 1: 47-60. 1996.

Huque QME. Poultry research and development in Bangladesh. In: Proceedings of the $1^{\text {st }}$ International Poultry show and Seminar. The World's Poultry Science Association-Bangladesh Branch, pp. 70-80. 1999.

Huque QME, Chowdhury SA, Haque ME and Sil BK. Poultry research in Bangladesh: Present status and its implication for future research. In: Proceedings of the $2^{\text {nd }}$ International Poultry Show and Seminar. The World's Poultry Science Association-Bangladesh Branch, pp: 15-24. 2001.

Huque QME and Haque ME. The onset of lay in indigenous hens following hatching of chicks. Poultry Adviser, 12: 57-60. 1990.

Huque QME and Salahuddin M. Identification and evaluation of 
native chicken. Progress Report. Poultry Production Research Division. BLRI, Savar, Dhaka, Bangladesh. 2001.

Hutt FB. Genetic resistance to disease in domestic animals. Cornell University Press, Ithaca, New York. 1958.

Islam ABMM, Hoque MM and Rahim QME. Reproductive performance of upgraded indigenous chicken. Poultry Adviser, 14: 33-36. 1981.

Islam MA. Effect of local and exotic strains of chicken for broiler production at hot-humid climate. Ph.D. Thesis. Institute of Animal Science, Faculty of Agriculture and Horticulture, Humboldt University of Berlin, Germany. 2000.

Islam MA. Comparison between sex-linked dwarf and normal broiler breeder hens for fertility, hatchability and growth performances at hot humid climate. Progressive Agriculture, 15: 61-66. 2004.

Islam MA. Comparative egg production and egg quality of indigenous full feathered and naked neck chicken at hothumid climate. Bangladesh Journal of Animal Science, 35: 99-105. 2006.

Islam MA, Bulbul S, Seeland G, Howlider MAR and Islam ABMM. Growth and egg production of local and exotic broiler parents in tropical environment. The Bangladesh Veterinarian, 17: 111-117. 2000.

Islam MA, Bulbul S, Seeland G and Islam ABMM. Egg quality of different chicken genotypes in summer and winter. Pakistan Journal of Biological Sciences, 4: 1411-1414. 2001a.

Islam MA and Nishibori M. Indigenous naked neck chicken: a valuable genetic resource for Bangladesh. World's Poultry Science Journal, 65: 125-138. 2009.

Islam MA, Seeland G, Bulbul SM and Howlider MAR. Meat yield and cooked meat taste of hybrids from different genetic groups in a hot-humid climate. Indian Journal of Animal Research, 36: 35-38. 2002a.

Islam MA, Seeland G, Horst P, Bulbul SM and Howlider MAR. Broiler production by crossing of local (indigenous) and exotic strains of the chicken under hot-humid climate. The Bangladesh Veterinarian, 19: 103-108. 2002b.

Islam MA, Seeland G, Horst P and Howlider MAR. Interaction of genetic group and season on fertility and hatchability of chicken eggs under adverse tropical environment. The Bangladesh Veterinarian, 18: 141-147. $2001 \mathrm{~b}$.

Kamble KD, Singh DP, Jori DC and Sharma RD. Reproductive performance of various Indian native breeds and their crosses with Dahlem Red. In: Proceedings of the XX World's Poultry Congress, IV, pp. 36. 1996.

Khan AG. Improvement of deshi birds-Part 2. Poultry Adviser, 16: 67-78. 1983.

Khondoker MAMY, Faruque MO, Howlider MAR and Ali A. Performance of upgraded indigenous desi chicken under farm condition. Bangladesh Journal of Animal Science, 25: 85-89. 1996.

Latif MA. Development strategies of livestock and poultry in Bangladesh. In: Proceedings of the $2^{\text {nd }}$ International Poultry Show and Seminar. The World's Poultry Science AssociationBangladesh Branch, pp: 27-33. 2001.

Merat P. Potential usefulness of the Na (naked neck) genes in poultry production. World's Poultry Science Journal, 42: 124-142. 1986.

Miah MS, Islam MA and Ali MA. Growth and egg production performance of exotic pure breeds and crossbreds chicken.
The Bangladesh Veterinarian, 19: 43-47. 2002.

Okoye JOA and Aba-Adulugba EP. Comparative study of the resistance or susceptibility of local Nigerian and exotic chickens to infectious bursal disease. In: Proceedings of the XX World's Poultry Congress, 11. 1996.

Paul BP, Howlider MAR and Bulbul SM. Comparison of meat yield between free range desi and broiler chicken. Indian Journal of Animal Sciences, 60: 866-868. 1990.

Peebles ED and Brake J. Egg shell quality and hatchability in broiler breeder eggs. Poultry Science, 66: 596-604. 1987.

Rahman M, Islam MN, Sarker NR and Islam MM. Effect of supplementary feeding on production performance of RIR, Fayoumi and their crossbred chicken in rural Bangladesh. Bangladesh Journal of Livestock Research, 1: 184-193. 1998.

Rahman M, Sorensen P, Jensen HA and Dolberg F. Exotic hens under semi-scavenging conditions in Bangladesh. Livestock Research for Rural Development, 9: http://www.cipav.org. co/Irrd9/3/bang931.htm. 1997.

Rahman MA, Baqui MA and Howlider MAR. Egg production performances of RIR $\times$ Fayoumi and Fayoumi $\times$ RIR crossbred chicken under intensive management. In: Bangladesh Livestock Research for Rural Development, 16: http:// www.cipav.org.co./Irrd/Irrd16/11/rahm16092.htm. 2004.

Salahuddin M and Howlider MAR. Effect of breed and season on egg quality traits of fowl. Indian Journal of Animal Sciences, 61: 859-863. 1991.

Sarkar K and Bell JG. Potentialities of the indigenous chicken and its role in poverty alleviation and nutrition security for rural households. INFPD Newsletter, 16: 15-26. 2006.

Shivaprasad HM, Loknath GR, Manjunath V, Kummer KSP and Murthy NHN. Performance of genotype with or without gene for naked neck. Poultry Adviser, 27: 45-52. 1994.

Singh DP, Johari DC, Mohapatra SC and Sharma RD. Efficiency of growth and production performance of four Indian native breeds of chicken. In: Proceedings of the XX World's Poultry Congress, 4, pp. 18. 1996.

Singh DP, Johri, TS, Singh UB, Narayan R and Singh D. Impact of constraints minimization on productivity and popularity of traditional backyard poultry production. In: Proceedings of the XXII World's Poulttry Congress. 2004.

Sorensen P. Results of the German Random sample Test 1995/ 1996. Dansk Erhversfjerie, pp. 239-249. 1997.

Sorensen $\mathrm{P}$ and Ssewannyana E. Progress in SAARI chicken breeding project-Analysis of growth capacity. DANIDA's Agricultural Sector Research Programme and NARO, Kampala, Uganda, pp. 172-178. 2003.

Tadelle D, Alemu Y and Peters KJ. Indigenous chicken in Ethiopia: their genetic potential, attempts at improvement. World's Poultry Science Journal, 56: 45-54. 2000.

Valle-Zarate A, Horst P, Harren-Kiso AV and Rahman A. Comparative performance of Egyptian local breeds and high yielding German medium-heavy brown layers under controlled temperature and warm environmental conditions. In: Proceedings of the XVIII World's Poultry Congress, pp. 389-391. 1988.

Yeasmin T and Howlider MAR. Comparative physical feature, egg production and egg quality characteristics of normal and dwarf indigenous (Desi) hens of Bangladesh. Journal of Applied Animal Research, 13: 191-196. 1998. 